\title{
Research Concerning the Variability of the Main Characteristics of Lettucefrom V.R.D.S. Buzau Germplasm Collection
}

\author{
Eliza TEODORESCU ${ }^{1}$ \\ ${ }^{1}$ Vegetable Research and Development Station, Mesteacanului Street, № 23, 120024, Buzau, Romania \\ *)corresponding author, e-mail: neicu_eliza@yahoo.com
}

BulletinUASVM Horticulture 72(2) / 2015

Print ISSN 1843-5254, Electronic ISSN 1843-5394

DOI:10.15835/buasvmcn-hort:10630

\begin{abstract}
Lettuce (Lactuca sativa L.) is the most important crop in the group of leafy vegetables. Lately, the nutritionists recommend more often lettuce consumption because of its high content in vitamins, mineral salts, nutrient substances and low content in carbohydrates. Research made at V.R.D.S. Buzau respond to two major problems: biodiversity conservation and creating new vegetable varieties adapted to nowadays climatic conditions. Since 2011 started the collection of biological material at this species from Buzau vegetable area. In this sense, the lettuce collection from V.R.D.S. Buzau contains over 30 accessions. This study presents the main characteristics of 10 accessions cultivated in open field in 2013 - 2014 period. In what it concerns accession 14, in 2013 there were registered the highest values of plant characteristics (height $-26 \mathrm{~cm}$, diameter $-36 \mathrm{~cm}$, weight $-504.33 \mathrm{~g}$ ) and edible part weight (319.33 g), while in 2014 the values of this accession reached or surpassed the mean value of the experience. All studied accessions, reached heads at the consumption maturity, except accession 18. Most variants had green leafs, while only 3 accessions $(8,15$ and 18) had anthocyanin coloration.
\end{abstract}

Keywords: breeding, conservation of biodiversity, germplasm collection, Lactuca sativa L., vegetables.

\section{INTRODUCTION}

Lettuce is one of the vegetables widely consumed all over the year. Its rather short vegetation period and resistance to low temperatures, permit the extension of consumption period even for extra-season, in protected areas (Lazar et al., 2012).

Most modern diets require daily intake of fresh vegetables for supplying the organism with natural vitamins and minerals. Grubben (2014) shows that $100 \mathrm{~g}$ dry matter lettuce contains: macronutrients $(19 \mathrm{~g}$ protein, $4.3 \mathrm{~g}$ fat, $41.4 \mathrm{~g}$ available carbohydrate, $21.7 \mathrm{~g}$ fibre and 13.6 $\mathrm{g}$ ash), minerals (Ca $489 \mathrm{mg}$, Fe $14.1 \mathrm{mg}$ and $\mathrm{Zn}$ $5.3 \mathrm{mg})$, energy (236 kcal) and vitamins $(20.271 \mu \mathrm{g}$ $\beta$-carotene equivalent, $1.1 \mathrm{mg}$ thiamine, $2.71 \mathrm{mg}$ riboflavin, $1.611 \mu \mathrm{g}$ folate and $96 \mathrm{mg}$ vit. C).
The ONU conference for environment and development, from Rio de Janeiro (1992), was the international political event in witch the conservation of biodiversity was included in environment problems. The reduction of genetic diversity of crop plants is as high and actual problem as the specific one (Maxim et al., 2007).

Brezeanu (2012) shows that in Romania alarming losses were recorded in all plant species, including vegetable.

According to the National Meteorological Administration (N.M.A.) Bucharest (2014) the amount of effective precipitations (Fig.1, a) is nowadays $260 \mathrm{~mm}$ precipitation/vegetation period, and in the future this value can be reduced to a half. Corresponding to the same source, soil water deficiency (Fig, 1, b) will increase at over $150 \mathrm{~mm}$ precipitation/season. 


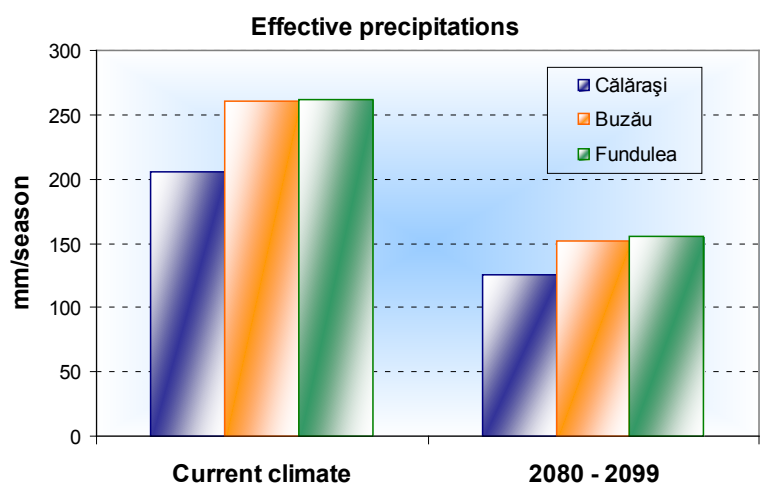

a)

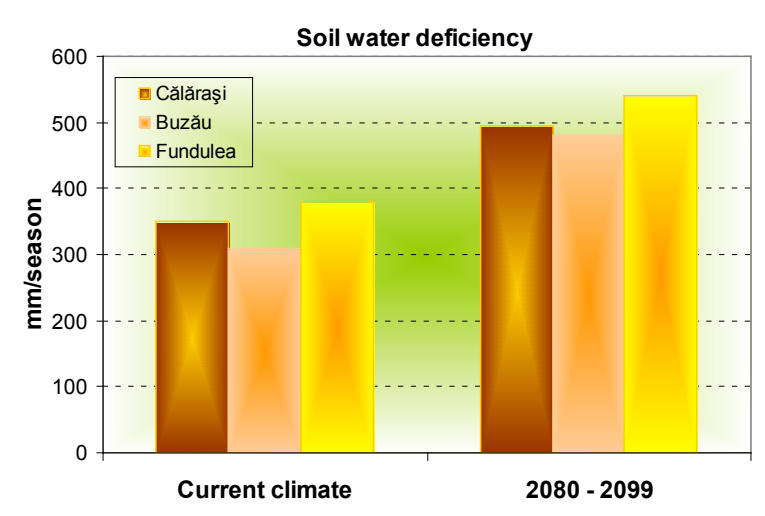

b)

Fig. 1 N.M.A. prognostic concerning effective precipitations (a) and soil water deficiency (b)

Since 2011, at V.R.D.S. Buzau there were started preservation and valorization programs concerning the vegetable patrimony with phenotypic useful expression and high ecological plasticity. In this sense, the lettuce collection from V.R.D.S. Buzău contains over 30 accessions.

Similar actions were made in USAMV Cluj-Napoca (2005) in collaboration with a French research group (Maxim et al., 2007).

The purposes of these researches are biodiversity conservation of lettuce and creating new varieties adapted to nowadays pedoclimatic conditions.

\section{MATERIALS AND METHODS}

The experiment took pace at V.R.D.S. Buzau during 2013-2014. From the lettuce germplasm collection, there were selected most representative 10 accessions. Therefore, the experimental variants were the following:

$\mathrm{V}_{1}$ - accession 3;

$\mathrm{V}_{2}$ - accession 7;

$\mathrm{V}_{3}$ - accession 8;

$\mathrm{V}_{4}$ - accession 10 ;

$\mathrm{V}_{5}$ - accession 11 ;

$\mathrm{V}_{6}-\operatorname{accession} 14 ;$
$\mathrm{V}_{7}-\operatorname{accession} 15 ;$
$\mathrm{V}_{8}-\operatorname{accession} 16 ;$
$\mathrm{V}_{9}-\operatorname{accession} 18 ;$
$\mathrm{V}_{10}-\operatorname{accession} 19$.

The crop was started by seedlings, sowed during the second decade of March and planted in the third decade of April (2013) and in the first decade of April (2014). The planting density was 70,000 plants/ha $(70 / 20 \mathrm{~cm})$.The harvest was made at the beginning of June.

The experiment was organized according to the randomized blocks method with 3 replications. The surface of each experimental plot was aproximatively $20 \mathrm{~m}^{2}$ and the results obtained were compared with the mean of the experience.In order to analise the results the analysis of variance and multiple comparison method (Duncan`s test) were used.

The biological material was cultivated in open field conditions, according to the technology recommended by the specialty literature (Ciofu et al., 2003; Indrea et al, 2012).

The determination of plants characteristics was done according to U.P.O.V. guideline (2006) and C.P.V.O. protocol (2011).

There were made biometric mensurements concerning the main plants characteristics (height, diameter, weight and edible weight), main heads characteristics (height, diameter, weight and no of leaves/head) and main characteristics of leaves (length, width, weight and no of leaves/plant).

In what it concerns lettuce, the commercial value is given by the weight of the edible part. Plants weight shows the potential of each variant. The difference between the plants weight and edible parts weight is determined by the culture technology that had been used.

\section{RESULTS AND DISCUSSION}

When the first leaf appeared, the seedlings of $V_{6}$ variant were dark green (Fig. 2, a). The seedlings of $\mathrm{V}_{9}$ variant presented a delicate anthocyanin coloration in the first development period (Fig. 2, b). Seedlings growing determined the emphasizing of this characteristic (Fig. 2, c) 


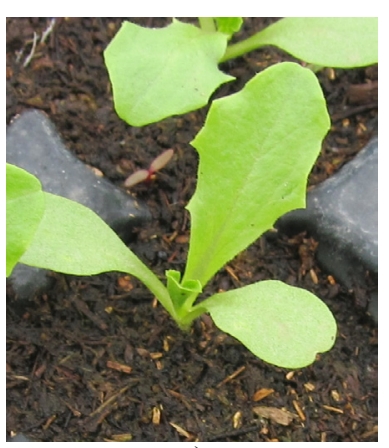

a)

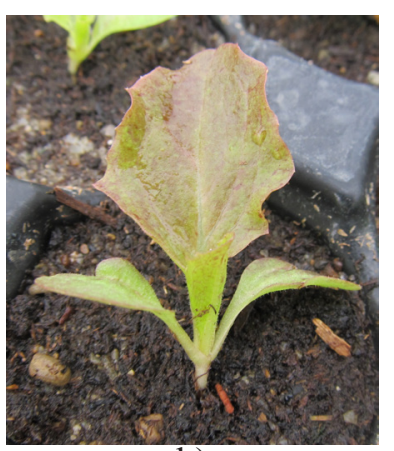

b)

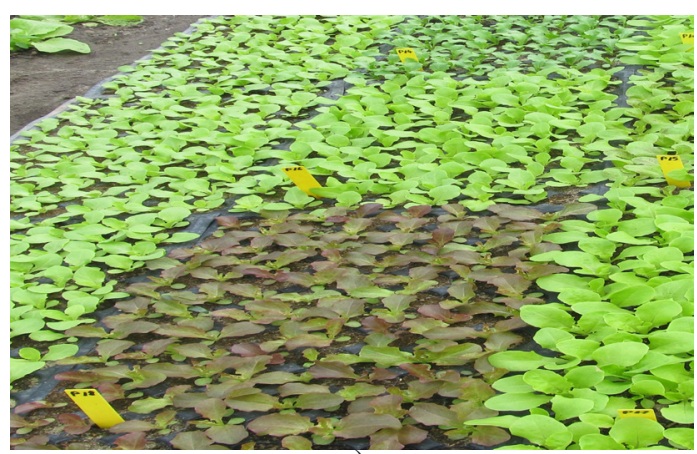

c)

Fig. 2 Seedlings from $V_{6}(a), V_{9}$ (b) variants and aspect from seedling culture (c)

Tab. 1 Main plants characteristics

\begin{tabular}{ccccccccc}
\hline \multirow{2}{*}{ Variants } & \multicolumn{2}{c}{ Height $(\mathrm{cm})$} & \multicolumn{2}{c}{ Diameter $(\mathrm{cm})$} & \multicolumn{2}{c}{ Weight $(\mathrm{g})$} & \multicolumn{2}{c}{ Edible weight (g) } \\
\cline { 2 - 9 } & 2013 & 2014 & 2013 & 2014 & 2013 & 2014 & 2013 & 2014 \\
\hline 1 & $17.33 \mathrm{c}$ & $15.77 \mathrm{ef}$ & $14.67 \mathrm{e}$ & $16.40 \mathrm{f}$ & $264.33 \mathrm{bcd}$ & $162.45 \mathrm{c}$ & $217.33 \mathrm{abc}$ & $128.94 \mathrm{~d}$ \\
\hline 2 & $13.83 \mathrm{~d}$ & $17.43 \mathrm{cde}$ & $19.33 \mathrm{de}$ & $27.57 \mathrm{abcd}$ & $234.00 \mathrm{bcd}$ & $339.47 \mathrm{ab}$ & $186.33 \mathrm{bcd}$ & $269.02 \mathrm{ab}$ \\
\hline 3 & $16.83 \mathrm{~cd}$ & $20.53 \mathrm{~b}$ & $24.00 \mathrm{~cd}$ & $25.97 \mathrm{bcde}$ & $252.00 \mathrm{bcd}$ & $245.04 \mathrm{abc}$ & $199.33 \mathrm{abcd}$ & $181.61 \mathrm{bcd}$ \\
\hline 4 & $17.33 \mathrm{c}$ & $17.53 \mathrm{cde}$ & $28.67 \mathrm{bc}$ & $26.77 \mathrm{abcd}$ & $373.00 \mathrm{ab}$ & $358.42 \mathrm{a}$ & $303.67 \mathrm{ab}$ & $277.01 \mathrm{a}$ \\
\hline 5 & $16.33 \mathrm{~cd}$ & $15.87 \mathrm{def}$ & $21.00 \mathrm{de}$ & $23.50 \mathrm{de}$ & $124.00 \mathrm{~d}$ & $241.11 \mathrm{abc}$ & $90.67 \mathrm{~d}$ & $180.80 \mathrm{bcd}$ \\
\hline 6 & $26.00 \mathrm{a}$ & $19.57 \mathrm{bc}$ & $36.00 \mathrm{a}$ & $25.63 \mathrm{cde}$ & $504.33 \mathrm{a}$ & $275.37 \mathrm{abc}$ & $319.33 \mathrm{a}$ & $232.27 \mathrm{abc}$ \\
\hline 7 & $14.00 \mathrm{~d}$ & $18.23 \mathrm{bcd}$ & $25.00 \mathrm{~cd}$ & $29.97 \mathrm{ab}$ & $270.00 \mathrm{bcd}$ & $351.56 \mathrm{a}$ & $206.00 \mathrm{abcd}$ & $265.62 \mathrm{ab}$ \\
\hline 8 & $17.33 \mathrm{c}$ & $20.37 \mathrm{~b}$ & $25.00 \mathrm{~cd}$ & $28.40 \mathrm{abc}$ & $199.33 \mathrm{bcd}$ & $302.05 \mathrm{ab}$ & $142.33 \mathrm{~cd}$ & $207.17 \mathrm{abcd}$ \\
\hline 9 & $21.33 \mathrm{~b}$ & $24.67 \mathrm{a}$ & $32.33 \mathrm{ab}$ & $30.93 \mathrm{a}$ & $187.67 \mathrm{bcd}$ & $271.42 \mathrm{abc}$ & $139.67 \mathrm{~cd}$ & $204.08 \mathrm{abcd}$ \\
\hline 10 & $15.67 \mathrm{~cd}$ & $14.57 \mathrm{f}$ & $24.00 \mathrm{~cd}$ & $22.30 \mathrm{e}$ & $285.00 \mathrm{bc}$ & $223.01 \mathrm{bc}$ & $202.00 \mathrm{abcd}$ & $171.11 \mathrm{~cd}$ \\
\hline Mean & 17.60 & 18.45 & 25.00 & 25.74 & 269.37 & 276.99 & 200.67 & 211.76 \\
\hline Min & 13.83 & 14.57 & 14.67 & 16.40 & 124.00 & 162.45 & 90.67 & 128.94 \\
\hline Max & 26.00 & 24.67 & 36.00 & 30.93 & 504.33 & 358.42 & 319.33 & 277.01 \\
\hline LSD & 2.81 & 2.17 & 6.38 & 3.85 & 134.14 & 112.12 & 107.54 & 81.08 \\
LSD ${ }_{1 \%}$ & 3.85 & 2.98 & 8.74 & 5.28 & 183.96 & 153.76 & 147.49 & 111.19 \\
LSD & 5.24 & 4.06 & 11.90 & 7.18 & 250.39 & 209.28 & 200.75 & 151.35 \\
\hline Note: Different letters between variants denote significant differences (Duncan test, p $<0.05)$. & & &
\end{tabular}

and apparition of anthocyanin coloration at the seedlings of $\mathrm{V}_{7}$ variant.

At the harvest maturity there were made determinations regarding the main plant characteristics (height, diameter and weight), and also edible weight.

At $V_{6}$ variant, in 2013, there were registered the highest values concerning plant characteristics (height $-26 \mathrm{~cm}$, diameter $-36 \mathrm{~cm}$, weight -504.33 g) and edible weight ( $319.33 \mathrm{~g}$ ), while in 2014 the values of this accession reached or surpassed the mean value of the experience (Tab. 1).

Plant diameter registered the lowest values at $V_{1}$ for both experimental years. At $V_{1}$ variant in 2014 there were registered the lowest values concerning plants weight (162.45 g) and edible weight (128.94 g).

In 2014, height $(24.67 \mathrm{~cm})$ and plant diameter $(30.93 \mathrm{~cm})$ registered maximum values at $V_{9}$, and plants weight (358.42 g) and eatable weight $(277.01 \mathrm{~g})$ registered maximum values at $\mathrm{V}_{4}$.

In 2013 weather conditions had negatively influenced $V_{5}$ plants; plants weight was $124.00 \mathrm{~g}$ and edible weight was $90.67 \mathrm{~g}$. In 2014 the values of the two characteristics doubled. The analysis of variance confirmed the negative influence on $\mathrm{V}_{5}$ and the positive influence on $\mathrm{V}_{4}$ and $\mathrm{V}_{6}$ of 2013 years, concerning the two analysed characteristics. 
Plants height varied between $13.93-26.00$ $\mathrm{cm}$ in 2013 and $14.57-24.67 \mathrm{~cm}$ in 2014. In 2011 in Cluj, Apahidean (2012) observed a plant height within 16.6 and $23 \mathrm{~cm}$. The variation interval concerning this character was larger at Buzau because of the weather conditions of this area.

Studying the 2013 - 2014 evolution it can be observed that 2013 conditions favored $V_{1}$, $\mathrm{V}_{4}, \mathrm{~V}_{6}$ and $\mathrm{V}_{10}$ variants while 2014 had favorable

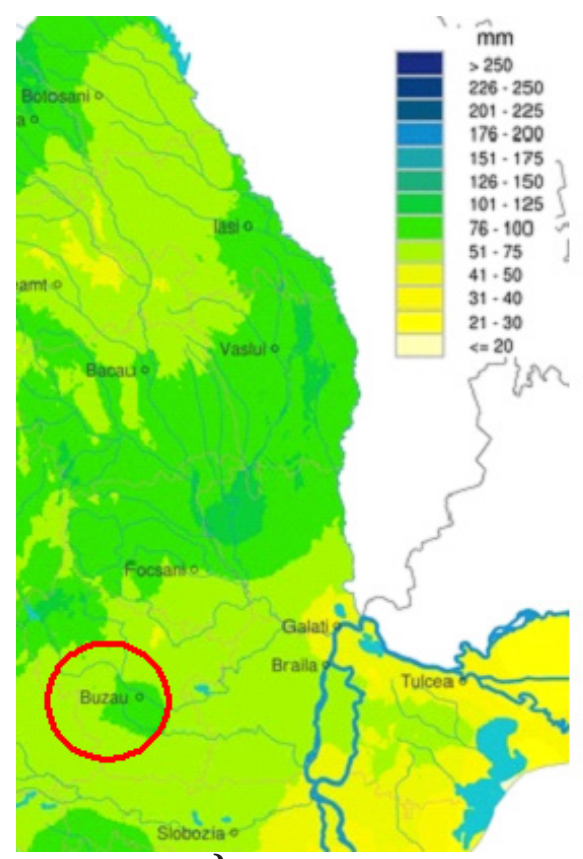

a)

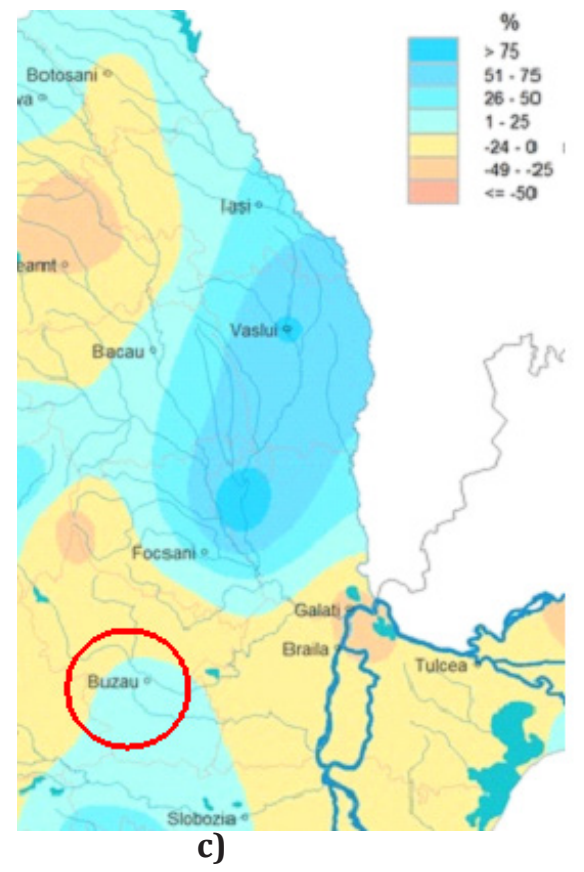

conditions for $\mathrm{V}_{2}, \mathrm{~V}_{5}, \mathrm{~V}_{7}, \mathrm{~V}_{8}$ and $\mathrm{V}_{9}$ variants. At $\mathrm{V}_{3}$ plants height and diameter were favored by 2013 conditions, while plants weight and edible weight were favored by 2014 conditions.

Concerning the studied parameters (Tab. 1), there was observed that the maximum values of 2013 were higher comparing to the maximum values obtained in 2014. Also, the minimum values of 2013 were lower than the minimum
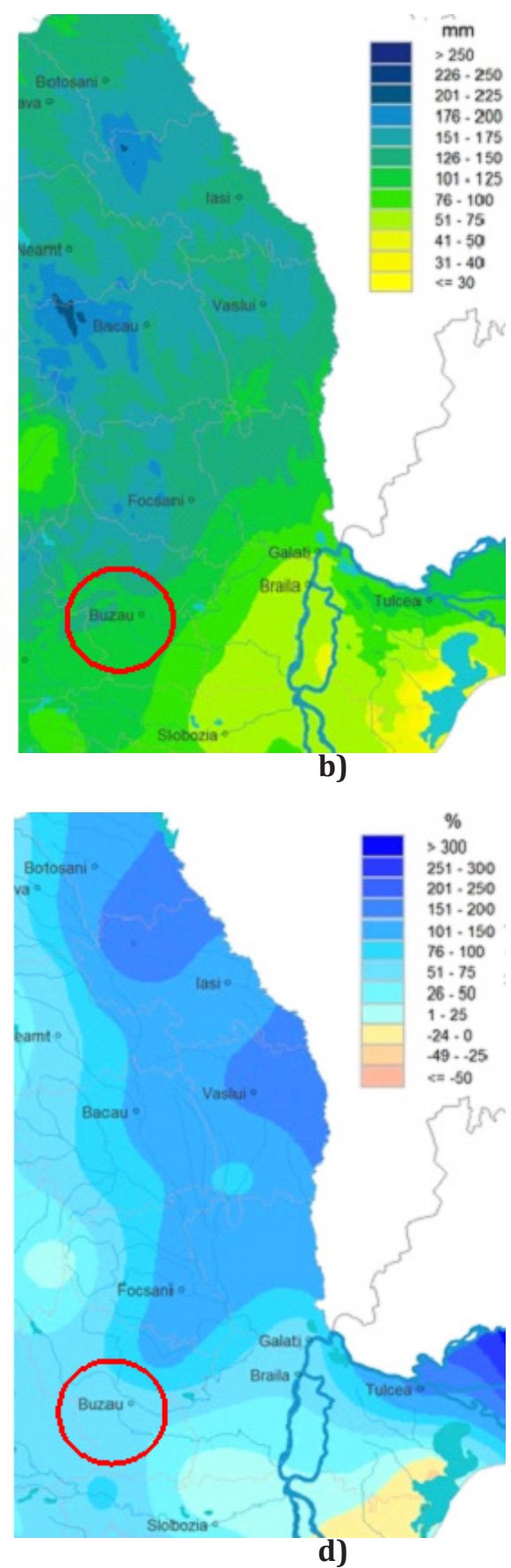

d)

Fig. 3 Precipitation quantity in May 2013 (a), May 2014 (b) and the digression of the precipitation quantity in May 2013 (c) and May 2014 (d) comparing to the multiannual quantities (1961 - 1990) according to NMA. http://www.meteoromania.ro. 
values of 2014. These values were determined by the different weather conditions of the two experimental years.

For Buzău area, concerning the precipitations quantity in May, it was observed that their value surpassed the mean quantity. In 2013, the precipitations quantity was within $76-100 \mathrm{~mm}$ (Fig. 3, a), with $1-25 \%$ more than the mean multiannual quantity (Fig. 3, c).

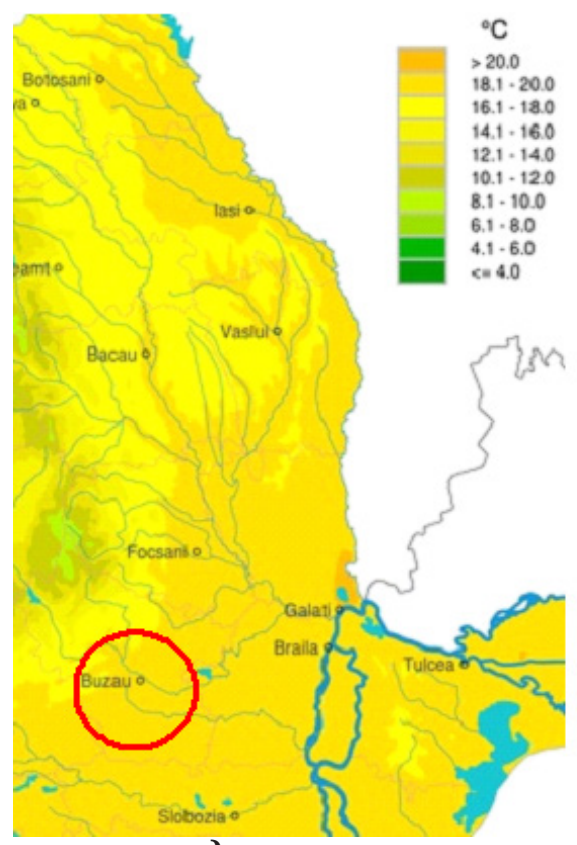

a)

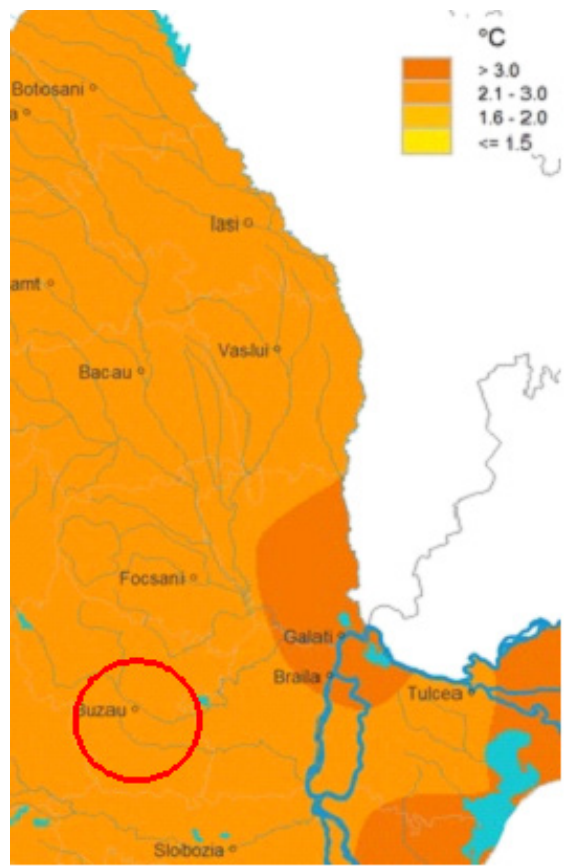

c)
In 2014 the quantity of precipitation in May was about $101-125 \mathrm{~mm}$ (Fig. 3, b), with $51-75 \%$ more than the mean multiannual quantity (Fig. 3, d).

The mean temperature in May 2013 was within $18.1-20^{\circ} \mathrm{C}$ (Fig. 4, a). This value is with 2.1 $-3.0^{\circ} \mathrm{C}$ (Fig. 4, c) bigger than the mean multiannual value.

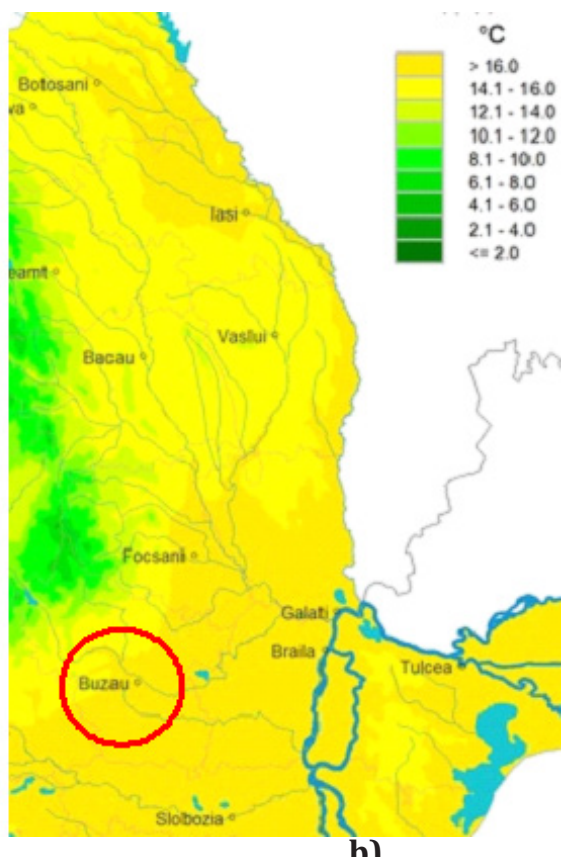

b)

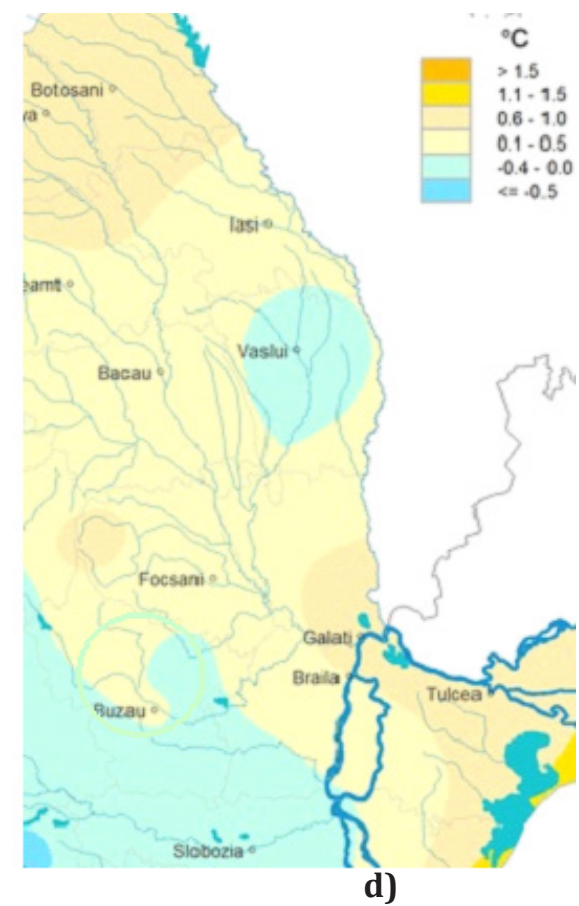

Fig. 4 Mean temperature in May 2013 (a), May 2014 (b) and the digression from the multiannual mean (1961 - 1990) in 2013 (c) and 2014 (d) according to NMA. - http://www.meteoromania.ro. 
Tab. 2 Main heads characteristics

\begin{tabular}{ccccccccc}
\hline \multirow{2}{*}{ Variants } & \multicolumn{2}{c}{ Height $(\mathrm{cm})$} & \multicolumn{2}{c}{ Diameter $(\mathrm{cm})$} & \multicolumn{2}{c}{ Weight $(\mathrm{g})$} & \multicolumn{2}{c}{ No of leaves/head } \\
\cline { 2 - 9 } & 2013 & 2014 & 2013 & 2014 & 2013 & 2014 & 2013 & $\mathbf{2 0 1 4}$ \\
\hline $\mathbf{1}$ & $13.50 \mathrm{bc}$ & $11.53 \mathrm{~b}$ & $9.83 \mathrm{bcd}$ & $5.60 \mathrm{c}$ & $170.00 \mathrm{a}$ & $78.68 \mathrm{bc}$ & $26.00 \mathrm{~cd}$ & $16.67 \mathrm{c}$ \\
\hline $\mathbf{2}$ & $13.00 \mathrm{c}$ & $13.43 \mathrm{ab}$ & $11.33 \mathrm{abc}$ & $13.13 \mathrm{a}$ & $113.67 \mathrm{abc}$ & $180.96 \mathrm{a}$ & $33.67 \mathrm{ab}$ & $27.67 \mathrm{a}$ \\
\hline $\mathbf{3}$ & $15.00 \mathrm{~b}$ & $11.27 \mathrm{~b}$ & $13.67 \mathrm{a}$ & $12.13 \mathrm{a}$ & $113.00 \mathrm{abc}$ & $106.68 \mathrm{ab}$ & $29.33 \mathrm{bc}$ & $20.83 \mathrm{bc}$ \\
\hline $\mathbf{4}$ & $13.33 \mathrm{bc}$ & $13.37 \mathrm{ab}$ & $11.00 \mathrm{abc}$ & $13.13 \mathrm{a}$ & $161.67 \mathrm{a}$ & $188.64 \mathrm{a}$ & $38.67 \mathrm{a}$ & $23.00 \mathrm{~b}$ \\
\hline $\mathbf{5}$ & $12.33 \mathrm{c}$ & $12.97 \mathrm{ab}$ & $8.00 \mathrm{~d}$ & $11.33 \mathrm{ab}$ & $42.00 \mathrm{de}$ & $122.06 \mathrm{ab}$ & $22.33 \mathrm{de}$ & $18.67 \mathrm{c}$ \\
\hline $\mathbf{6}$ & $18.00 \mathrm{a}$ & $17.10 \mathrm{a}$ & $8.67 \mathrm{~cd}$ & $12.00 \mathrm{a}$ & $70.00 \mathrm{bcd}$ & $124.97 \mathrm{ab}$ & $9.67 \mathrm{~g}$ & $10.67 \mathrm{~d}$ \\
\hline $\mathbf{7}$ & $12.33 \mathrm{c}$ & $14.80 \mathrm{ab}$ & $12.67 \mathrm{ab}$ & $13.07 \mathrm{a}$ & $128.33 \mathrm{ab}$ & $185.15 \mathrm{a}$ & $22.67 \mathrm{de}$ & $20.00 \mathrm{bc}$ \\
\hline $\mathbf{8}$ & $12.33 \mathrm{c}$ & $13.73 \mathrm{ab}$ & $7.00 \mathrm{~d}$ & $11.83 \mathrm{ab}$ & $28.33 \mathrm{de}$ & $129.42 \mathrm{ab}$ & $17.33 \mathrm{ef}$ & $17.00 \mathrm{c}$ \\
\hline $\mathbf{9}$ & $0.00 \mathrm{e}$ & $0.00 \mathrm{c}$ & $0.00 \mathrm{e}$ & $0.00 \mathrm{~d}$ & $0.00 \mathrm{e}$ & $0.00 \mathrm{c}$ & $0.00 \mathrm{~h}$ & $0.00 \mathrm{e}$ \\
\hline $\mathbf{1 0}$ & $10.33 \mathrm{~d}$ & $12.97 \mathrm{ab}$ & $7.33 \mathrm{~d}$ & $8.90 \mathrm{~b}$ & $53.33 \mathrm{cde}$ & $83.04 \mathrm{bc}$ & $15.33 \mathrm{fg}$ & $9.33 \mathrm{~d}$ \\
\hline Mean & $\mathbf{1 2 . 0 2}$ & $\mathbf{1 2 . 1 2}$ & $\mathbf{8 . 9 5}$ & $\mathbf{1 0 . 1 1}$ & $\mathbf{8 8 . 0 3}$ & $\mathbf{1 1 9 . 9 6}$ & $\mathbf{2 1 . 5 0}$ & $\mathbf{1 6 . 3 8}$ \\
\hline Max & 18.00 & 17.10 & 13.67 & 13.13 & 170.00 & 188.64 & 38.67 & 27.67 \\
\hline LSD $_{5 \%}$ & 1.72 & 4.85 & 2.77 & 2.85 & 62.33 & 86.34 & 5.99 & 3.88 \\
LSD $_{1 \%}$ & 2.36 & 6.65 & 3.80 & 3.91 & 85.48 & 118.41 & 8.22 & 5.32 \\
LSD $_{\text {010 }}$ & 3.21 & 9.06 & 5.17 & 5.33 & 116.35 & 161.17 & 11.19 & 7.24 \\
\hline Note: Different letters between variants denote significant differences (Duncan test, p<0.05). & & &
\end{tabular}

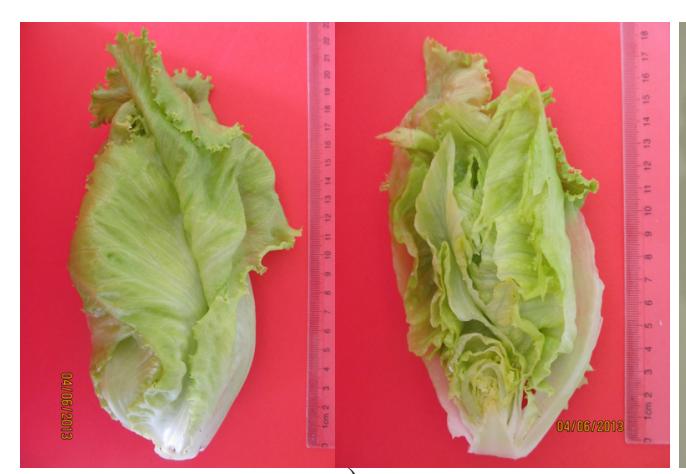

a)

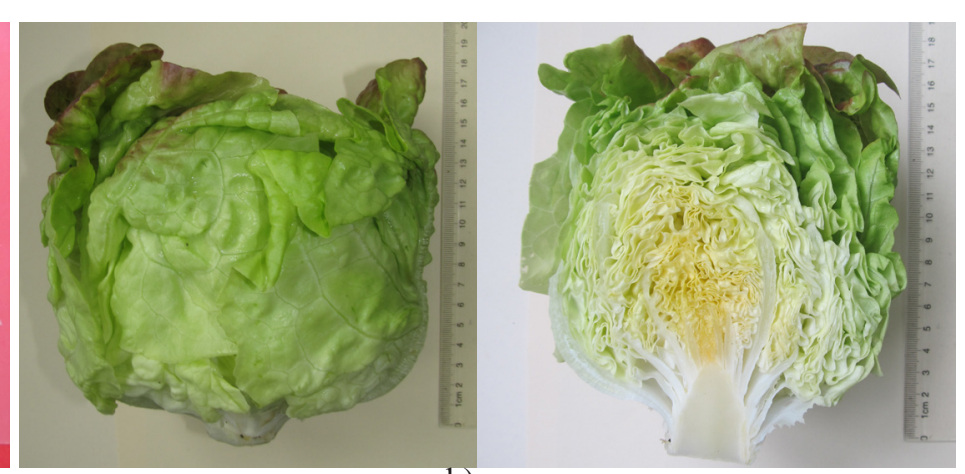

b)

Fig. 5 Head shape at $V_{6}(a)$ and at $V_{7}(b)$ variants

May 2014 had a mean temperature bigger than $16^{\circ} \mathrm{C}$ (Fig. 4, b), fact that represents a digression from the mean multiannual value of $0.1-0.5^{\circ} \mathrm{C}$ (Fig. 4, d).

The high quantity of precipitations in 2014 corroborated with the temperatures close to the lettuce requirements (Ciofu et al., 2003) determined a decrease of the differences registered between the variants comparing to 2013 .

All accessions presented reached head at the consumption maturity, except $\mathrm{V}_{9}$ variant.

The climatic conditions of 2014 favored the main head characteristics, except the number of leaves/head. Most variants registered bigger values of studied characteristics in 2014 comparing to 2013 (Tab. 2).
Heads weight in $V_{8}$ variant increased from $28.33 \mathrm{~g}$ in 2013 to $129.42 \mathrm{~g}$ in 2014 and in $\mathrm{V}_{5}$ variant increased from $42 \mathrm{~g}$ to $122.06 \mathrm{~g}$.

$V_{3}$ and $V_{1}$ variants are the only variants in this study where there was observed a decrease of all values in 2014 concerning head characteristics (Tab. 2). This decrease was caused by the Limax $s p$. attack, to which the two variants seem to be sensible.

Head height revealed maximum values of 18 $\mathrm{cm} \mathrm{(2013)} \mathrm{and} 17.1 \mathrm{~cm} \mathrm{(2014)} \mathrm{in} \mathrm{V}_{6}$ variant. The minimum values for this characteristic were of $10.33 \mathrm{~cm}$ in $\mathrm{V}_{10}$ (2013) and $11.27 \mathrm{~cm}$ in $\mathrm{V}_{3}$ variants (2014).

Head shape varied from narrow elliptic at $\mathrm{V}_{6}$ (Fig. 5, a) to circular at $\mathrm{V}_{7}$ (Fig. 5, b) variants. 


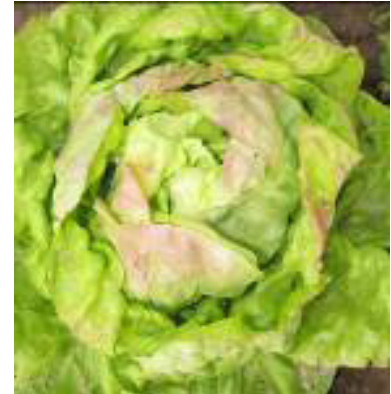

a)

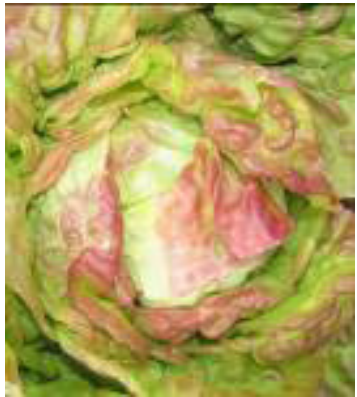

b)

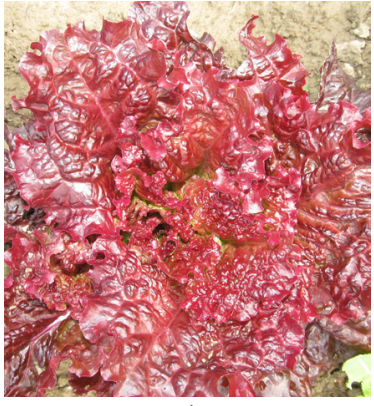

c)

Fig. 7 Anthocyanin coloration intensity at $V_{3}(a), V_{7}(b)$ and $V_{9}(c)$

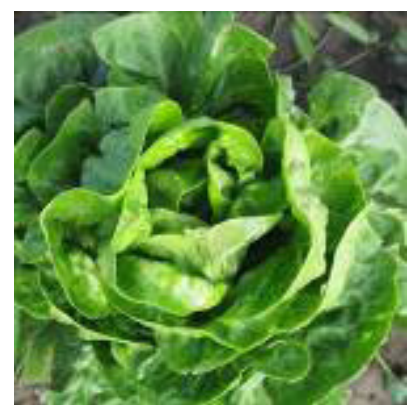

a)

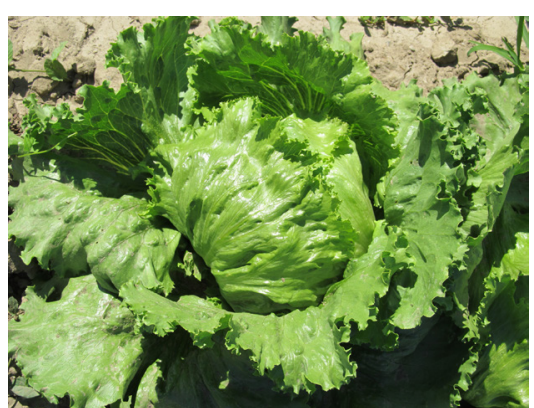

b)

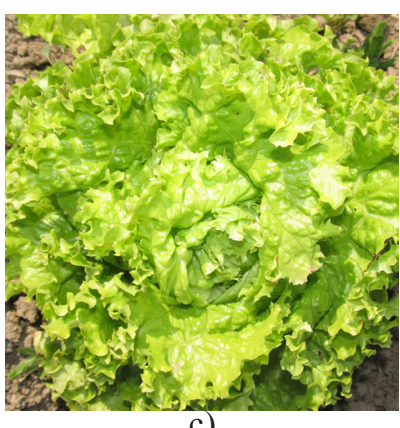

c)

Fig. 6 Green color intensity at $V_{1}(a), V_{6}(b), V_{2}(c)$ and $V_{4}(d)$

The external head color was green at most variants. Green color intensity was different at the studied varieties from dark green at $V_{1}$ (Fig. 6, a) and $V_{6}$ (Fig. 6, b) to light green at $V_{2}, V_{4}$ and $V_{10}$ (Fig. 6, c).

Anthocyanin coloration of the external head was observed at $\mathrm{V}_{3}$ (Fig. 7, a) and $\mathrm{V}_{7}$ (Fig. 7, b). The most intense anthocyanin coloration was observed at $\mathrm{V}_{9}$ (Fig. 7, c).

Climatic conditions in 2014 determined smaller values at $V_{1}$ and $V_{3}$ concerning the leaves characteristics (Tab. 3) comparative to the values registered in 2013.

There were observed very significant differences regarding $V_{6}$ during the two experimental years in what it concerns leaves length, width and weight. In 2013 leaf length at this variant was 26 $\mathrm{cm}$, width was $31.67 \mathrm{~cm}$ and weight was $48 \mathrm{~g}$. At the same variant there were registered distinct significant (2013) and very significant (2014) differences concerning the number of leaves/ plant. The decrease of weight leaf at $\mathrm{V}_{6}$ variant in 2014 (25.82 g) was caused by the Limax sp. attack.

At $V_{7}$ variant there was observed a high anthocyanin coloration on the entire leaf surface during the first development period (Fig. 8, a). Subsequently, leaf base was green and the anthocyanin coloration could have been seen only on the superior half of the leaf (Fig. 8, b) and on the external closed head (Fig. 7, b). Anthocyanin coloration was observed on the superior half of the leaf at $V_{9}$ variant (Fig. $7, c$ ).

Leaves shape was round at $V_{4}$ (Fig. 9, a), obovate at $V_{3}$ (Fig. 9, b), broad obtrullate at $V_{6}$ and $\mathrm{V}_{10}$ (Fig. 9, $\mathrm{c}$ and $\mathrm{d}$ ), and narrow elliptic at $\mathrm{V}_{9}$ (Fig. $8, \mathrm{c}$ ).

The foliar limb margin was entire at most variants and fimbriat at $V_{6}, V_{9}$ and $V_{10}$. The foliar limb surface was smooth at most variants, but at $\mathrm{V}_{7}$ and $\mathrm{V}_{9}$ was very embossed.

\section{CONCLUSION}

The high level of precipitations in 2014 corroborated with the temperatures close to the lettuce requirements determined a decrease of the differences registered between variants comparing to those registered in 2013, regarding the studied characteristics. The climatic conditions of 2013 year favored the variants $V_{1}, V_{4}, V_{6}$ and $\mathrm{V}_{10}$, while those of 2014 year were favorable to $\mathrm{V}_{2}, \mathrm{~V}_{5}, \mathrm{~V}_{7}, \mathrm{~V}_{8}$ and $\mathrm{V}_{9}$ variants. In $\mathrm{V}_{1}$ and $\mathrm{V}_{3}$ variants a decrease of the main head characteristics in 2014 comparing to 2013 was registered. $V_{1}$ and 
Tab. 3 Main leaves characteristics

\begin{tabular}{ccccccccc}
\hline \multirow{2}{*}{ Variants } & \multicolumn{2}{c}{ Length $(\mathrm{cm})$} & \multicolumn{2}{c}{ Width $(\mathrm{cm})$} & \multicolumn{2}{c}{ Weight $(\mathrm{g})$} & \multicolumn{2}{c}{ No of leaves/plant } \\
\cline { 2 - 9 } & $\mathbf{2 0 1 3}$ & $\mathbf{2 0 1 4}$ & $\mathbf{2 0 1 3}$ & $\mathbf{2 0 1 4}$ & $\mathbf{2 0 1 3}$ & $\mathbf{2 0 1 4}$ & $\mathbf{2 0 1 3}$ & $\mathbf{2 0 1 4}$ \\
\hline $\mathbf{1}$ & $13.50 \mathrm{f}$ & $14.23 \mathrm{f}$ & $11.50 \mathrm{~d}$ & $10.17 \mathrm{f}$ & $14.33 \mathrm{bc}$ & $7.34 \mathrm{c}$ & $34.33 \mathrm{~cd}$ & $30.67 \mathrm{de}$ \\
\hline $\mathbf{2}$ & $16.33 \mathrm{cde}$ & $19.60 \mathrm{~cd}$ & $15.00 \mathrm{bc}$ & $16.70 \mathrm{bcd}$ & $9.67 \mathrm{cde}$ & $11.65 \mathrm{c}$ & $46.67 \mathrm{~b}$ & $41.33 \mathrm{ab}$ \\
\hline $\mathbf{3}$ & $18.67 \mathrm{bc}$ & $22.57 \mathrm{ab}$ & $15.83 \mathrm{bc}$ & $17.97 \mathrm{~b}$ & $15.33 \mathrm{bc}$ & $8.66 \mathrm{c}$ & $41.67 \mathrm{bc}$ & $39.33 \mathrm{ab}$ \\
\hline $\mathbf{4}$ & $18.00 \mathrm{c}$ & $18.63 \mathrm{de}$ & $17.33 \mathrm{~b}$ & $16.97 \mathrm{bc}$ & $12.67 \mathrm{bcd}$ & $12.36 \mathrm{c}$ & $61.67 \mathrm{a}$ & $43.00 \mathrm{a}$ \\
\hline $\mathbf{5}$ & $14.50 \mathrm{def}$ & $16.67 \mathrm{ef}$ & $13.50 \mathrm{~cd}$ & $14.63 \mathrm{cde}$ & $5.67 \mathrm{e}$ & $7.75 \mathrm{c}$ & $36.67 \mathrm{bcd}$ & $36.00 \mathrm{bcd}$ \\
\hline $\mathbf{6}$ & $26.00 \mathrm{a}$ & $25.00 \mathrm{a}$ & $31.67 \mathrm{a}$ & $21.87 \mathrm{a}$ & $48.00 \mathrm{a}$ & $25.82 \mathrm{a}$ & $23.00 \mathrm{e}$ & $22.67 \mathrm{f}$ \\
\hline $\mathbf{7}$ & $15.00 \mathrm{def}$ & $18.90 \mathrm{cde}$ & $15.33 \mathrm{bc}$ & $19.83 \mathrm{ab}$ & $16.33 \mathrm{~b}$ & $18.66 \mathrm{~b}$ & $34.67 \mathrm{~cd}$ & $33.00 \mathrm{~cd}$ \\
\hline $\mathbf{8}$ & $16.67 \mathrm{~cd}$ & $21.60 \mathrm{bc}$ & $12.83 \mathrm{~cd}$ & $16.90 \mathrm{bc}$ & $7.33 \mathrm{de}$ & $9.56 \mathrm{c}$ & $36.00 \mathrm{~cd}$ & $37.00 \mathrm{abc}$ \\
\hline $\mathbf{9}$ & $20.67 \mathrm{~b}$ & $24.57 \mathrm{a}$ & $16.13 \mathrm{bc}$ & $13.67 \mathrm{de}$ & $13.67 \mathrm{bc}$ & $12.03 \mathrm{c}$ & $31.33 \mathrm{cde}$ & $38.33 \mathrm{ab}$ \\
\hline $\mathbf{1 0}$ & $13.83 \mathrm{ef}$ & $14.07 \mathrm{f}$ & $17.33 \mathrm{~b}$ & $12.97 \mathrm{ef}$ & $17.33 \mathrm{~b}$ & $11.71 \mathrm{c}$ & $30.00 \mathrm{de}$ & $26.67 \mathrm{ef}$ \\
\hline Mean & 17.32 & 19.58 & 16.65 & 16.17 & 16.03 & 12.55 & 37.60 & 34.80 \\
\hline Max & 26.00 & 25.00 & 31.67 & 21.87 & 48.00 & 25.82 & 61.67 & 43.00 \\
\hline Min & 13.50 & 14.07 & 11.50 & 10.17 & 5.67 & 7.34 & 23.00 & 22.67 \\
\hline LSD $_{5 \%}$ & 2.49 & 2.67 & 3.17 & 2.98 & 6.15 & 5.65 & 9.71 & 5.49 \\
LSD $_{1 \%}$ & 3.42 & 3.66 & 4.34 & 4.09 & 8.43 & 7.74 & 13.31 & 7.52 \\
LSD $_{\text {N1\% }}$ & 4.65 & 4.98 & 5.91 & 5.56 & 11.48 & 10.54 & 18.12 & 10.24 \\
\hline Note: Different letters between variants denote significant differences (Duncan test, $\mathrm{p}<0.05)$. & & &
\end{tabular}

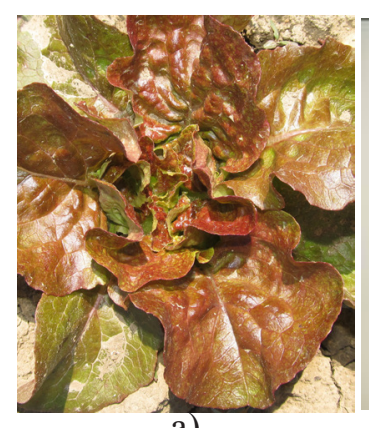

a)

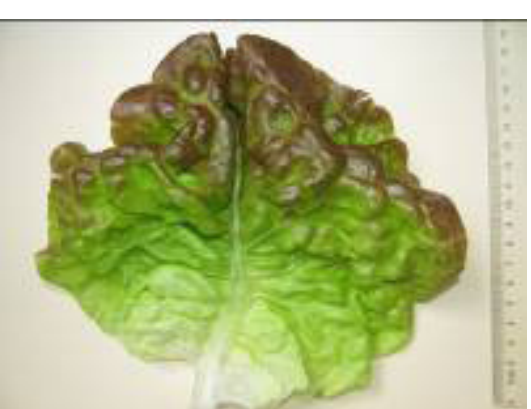

b)

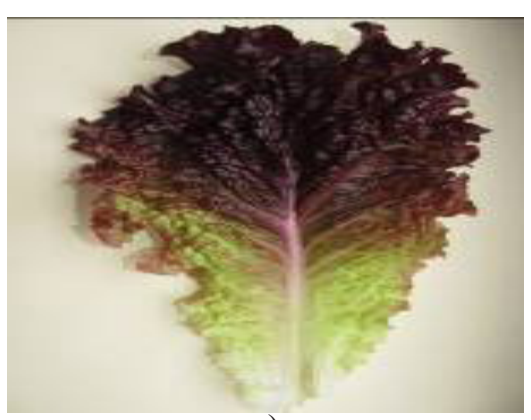

c)

Fig. 8 Leaf anthocyanin coloration intensity at $V_{7}(a$ and $b)$ and $V_{9}(c)$

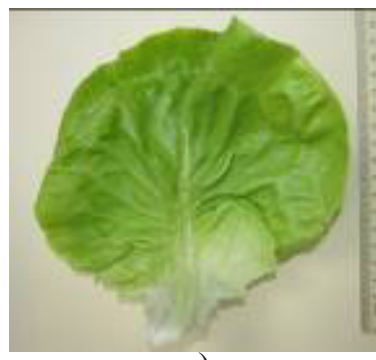

a)

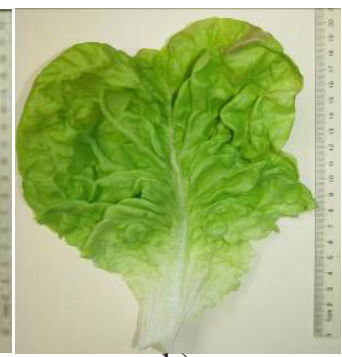

b)

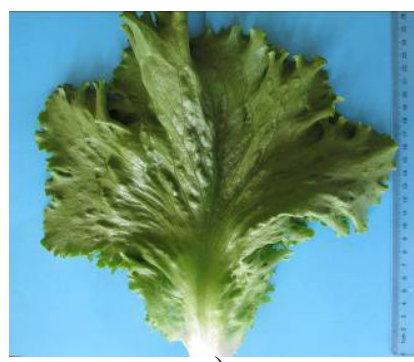

c)

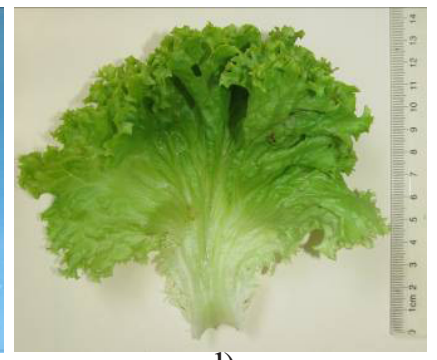

d)

Fig. 9 Leaf shape at $V_{4}(a), V_{3}(b), V_{6}(c)$ and $V_{10}(d)$

$\mathrm{V}_{3}$ variants presented sensibility to the Limax sp. attack in 2014 climatic conditions. The highest value regarding head height was registered at $V_{6}$ variant in both experimental years. Leaves length, width and weight registered maximum values in V6 variant in both experimental years.

Acknowledgements. This work was co-financed from A.D.E.R. 2020 Program, project A.D.E.R. 1.1.11. 


\section{REFERENCES}

1. Apahidean AS, Szabo J, Apahidean Maria, Apahidean AI , Laczi Eniko (2012). Studies upon a lettuce (Lactuca sativa L.) assortment grown in protected culture. Bulletin UASVM Horticulture, 69(1):372 - 373.

2. Brezeanu C, Brezeanu PM, Ambăruș S, Călin M (2012). Assesment of vegetable resources conservation work at Vegetable Research Station Bacau Romania. USAMV Iasi, Seria Horticultură, Editura "Ion Ionescu De La Brad”,Lucrări Științifice, Vol. 55(1): 157 - 160.

3. Ciofu R, Stan N, Popescu V, Chilon P, Apahidean S, Horgoș A, Berar V, Lauer KF , Atanasiu N (2003). Treaty gardening. Ceres Publishing house, Bucharest, 900 - 914 p.

4. Grubben G, Klaver W, Nono-Womdim R, Everaarts A, Fondio L, Nugteren JA and Corrado Marina (2014) Vegetable to combat the hidden hunger in Africa. Cronica Horticulturae, 54(1): $24-32$.

5. Indrea D, Apahidean AS, Apahidean Maria, Măniuțiu DN Sima Rodica (2012).Growing vegetables, Ceres Publishing house, Bucharest, $422-432$ p.
6. Lazar V, Sima R, Gocan T (2012). Influence of certain technological traits on yield quality in lettuce. Bulletin UASVM Horticulture, 69(1):198 - 202.

7. Maxim A, Sima R, Fițiu A, Sandor M, Papp R, Lucian C, Hapca A (2007). Preliminary results concerning the preservation of genetical diversity of different vegetable varieties at USAMV Cluj-Napoca. Bulletin USAMV-CN, 63: 291-296.

8. Săulescu NA, Săulescu NN (1967). The experimental field. Agro-silvică Publishing house, Bucharest, 165 - 216 p.

9. Community Plant Variety Office (C.P.V.O.) Switzerland (2011). Protocol for distinctness, uniformity and stability tests lettuce (Lactuca sativa L.). TG/13/5. Geneva.

10. International Union for the Protection of New Varieties of Plants (U.P.O.V.), Switzerland (2006). Guidelines for the conduct of tests for distinctness, uniformity and stability of lettuce (Lactuca sativa L.) TG/13/10. Geneva.

11. http://www.meteoromania.ro/anm/?page_id=423. 